\title{
Litterfall deposition and nutrient return in pine- oak forests and scrublands in northeastern Mexico
}

\section{Depósito de hojarasca y retorno de nutrientes en bosques de pino-encino y matorrales en el noreste de México}

\begin{abstract}
Humberto González-Rodríguez', Juan Manuel López-Hernández, Roque Gonzalo Ramírez-Lozanoł2, Marco Vinicio Gómez-Meza ${ }^{3}$, Israel Cantú-Silva', Jorge Isaac Sarquís-Ramírez ${ }^{4}$ and Arturo Mora-Olivo ${ }^{5}$
\end{abstract}

1 Universidad Autónoma de Nuevo León. Facultad de Ciencias Forestales. Linares, Nuevo León, México. 2 Universidad Autónoma de Nuevo León. Facultad de Ciencias Biológicas. San Nicolás de los Garza, Nuevo León, México.

\author{
3 Universidad Autónoma de Nuevo León. Facultad de \\ Economía. Monterrey, Nuevo León, México. \\ 4 Universidad Veracruzana. Facultad de Ciencias \\ Biológicas y Agropecuarias. Córdoba, Veracruz, \\ 5 Universidad Autónoma de Tamaulipas. Instituto de \\ Ecología Aplicada. Ciudad Victoria, Tamaulipas, \\ México. \\ * Corresponding author. juma_loher@hotmail.com
} México.

\begin{abstract}
Litterfall and its decomposition represents the main nutrient input in forest soils whereby organic matter is cycled, thus influencing the circulation of nutrients in ecosystems. Therefore, the aim of this study was to determine litterfall nutrient-input and deposition via fallen leaves. Litterfall was collected at three sites: 1) a pine-oak forest, 2) an ecotone in a transition zone between a pine-oak forest and a piedmont shrubland, and 3) a thorn scrub in the Tamaulipan thorn-scrub vegetation community. At each site, an experimental plot was selected to allocate ten litter canisters to collect litterfall. Total litterfall deposition was highest at the ecotone, followed by the thorn scrub and the pine-oak forest (hereupon, the pine-oak forest will be referred to as "pine forest" for simplicity) $\left(706.0 \mathrm{~g} \mathrm{~m}^{-2} \mathrm{year}^{-1}, 495.6 \mathrm{~g} \mathrm{~m}^{-2}\right.$ year ${ }^{-1}$, and $483.0 \mathrm{~g} \mathrm{~m}^{-2}$ year $^{-1}$, respectively). Leaf litter abundance was greater than that of twigs, reproductive structures, or miscellaneous components (385.3 $\mathrm{g} \mathrm{m}^{-2}$ year $^{-1}, 84.6 \mathrm{~g} \mathrm{~m}^{-2}$ year $^{-1}, 55.7 \mathrm{~g} \mathrm{~m}^{-2}$ year $^{-1}$, and $35.8 \mathrm{~g} \mathrm{~m}^{-2}$ year-1, respectively). Total deposition of nutrients (mg $\mathrm{m}^{-2}$ year $^{-1}$ ) varied as follows: Ca, from 3.7 (pine forest) to 13.5 (thorn scrub); K, from 1.0 (pine forest) to 3.8 (ecotone); $\mathrm{Mg}$, from 0.5 (pine forest) to 1.3 (ecotone); $\mathrm{N}$, from 2.7 (pine forest) to 8.3 (ecotone); P, from 0.1 (pine forest) to 0.3 (ecotone); $\mathrm{Cu}$, from 1.0 (pine forest) to 2.9 (ecotone); Fe, from 35.2 (pine forest) to 89.3 (ecotone); Mn, from 27.7 (pine forest) to 71.8 (ecotone), and $\mathrm{Zn}$ from 7.3 (thorn scrub) to 7.8 (ecotone). Litterfall and nutrient input was more abundant during the months of winter than at any other time of the year.
\end{abstract}

KEYWORDS: ecotone, leaves, piedmont shrubland, pine forest, thorn scrub, nutrient use efficiency.

\section{RESUMEN}

La caída de la hojarasca y su posterior descomposición representa el principal aporte de nutrientes al suelo y es uno de los procesos fundamentales del ciclado de la materia orgánica que influyen en el flujo de nutrientes en los ecosistemas. El objetivo de este estudio fue determinar los componentes y la deposición de nutrientes presentes en la hojarasca. La hojarasca se recolectó en tres sitios: 1) un bosque de pino, 2) un ecotono en zona de transición entre bosque de pino y matorral submontano y 3) un matorral espinoso en una comunidad vegetal del matorral espinoso tamaulipeco. En cada sitio se seleccionó una parcela experimental para ubicar en ella diez canastas colectoras de hojarasca, cuya deposición fue mayor en el ecotono, seguida del matorral espinoso y el bosque de pino $\left(706.0 \mathrm{~g} \mathrm{~m}^{-2}\right.$ año-1 $495.6 \mathrm{~g}$ $\mathrm{m}^{-2}$ año-1 y $483.0 \mathrm{~g} \mathrm{~m}^{-2}$ año-1, respectivamente). La caída de hojas fue mayor que la de ramas, de estructuras reproductivas o de componentes diversos (385.3 $\mathrm{g} \mathrm{m}^{-2}$ año-1, $84.6 \mathrm{~g} \mathrm{~m}^{-2}$ año-1 $55.7 \mathrm{~g} \mathrm{~m}^{-2}$ año-1 y $35.8 \mathrm{~g} \mathrm{~m}^{-2}$ año ${ }^{-1}$, respectivamente). La deposición de nutrientes $\left(\mathrm{g} \mathrm{m}^{-2}\right.$ año-1 $)$ varió de la siguiente forma: $\mathrm{Ca}$, de 3.7 (bosque de pino) a 13.5 (matorral espinoso); $\mathrm{K}$, de 1.0 (bosque de pino) a 3.8 (ecotono); $\mathrm{Mg}$, de 0.5 (bosque de pino) a 1.3 (ecotono); N, de 2.7 (bosque de pino) a 8.3 (ecotono); P, de 0.1 (bosque de pino) a 0.3 (ecotono); $\mathrm{Cu}$, de 1.0 (bosque de pino) a 2.9 (ecotono); Fe, de 35.2 (bosque de pino) a 89.3 (ecotono); Mn, de 27.7 (bosque de pino) a 71.8 (ecotono) y Zn de 7.3 (matorral espinoso) a 7.8 (ecotono). En los meses de invierno se observó mayor producción de hojarasca y aporte de nutrientes que en otros meses.

PALABRAS CLAVE: ecotono, hojas, matorral submontano, bosque de pino, matorral espinoso, uso eficiente de nutrientes. 


\section{INTRODUCTION}

Litterfall in forest ecosystems is composed by leaves, twigs $<2 \mathrm{~cm}$, flowers, fruits, bark fragments, and other plant parts that have fallen to the forest floor (GonzálezRodríguez et al., 2008; Celentano et al., 2011; Scoriza et al., 2012; Camargo et al., 2015; López-Hernández et al., 2015). Forest litter acts primarily as a route for the transfer of nutrients from vegetation to the soil and the rate at which forest litter falls - and subsequently decays - contribute to the regulation of nutrients, as well as to the maintenance of soil fertility, which is essential for the sustainability of forest systems over extended periods of time (Martín, Gallardo, \& Santa-Regina, 1996; Silver, Hall, \& González, 2014; Zhang, Yuan, Dong, \& Liu, 2014).

Litterfall is a measure of the net primary productivity of a given ecosystem and is strongly correlated with the increase in biomass, tree density and canopy openness; however, it is affected by other environmental constraints (such as rainfall, temperature and potential evapotranspiration), altitude, edaphic conditions, and anthropogenic disturbances (Oelbermann \& Gordon, 2000; Prause, Arce, \& Angeloni, 2003; Zaldívar-Jiménez, Herrera-Silveira, Coronado-Molina, \& Alonzo-Parra, 2004; Pavón, Briones, \& Flores-Rivas, 2005; Roig, del Rio, Canellas, \& Montero, 2005).

Litterfall input varies widely among forest ecosystems in terms of quantity and quality. In this regard, the interannual variation in litterfall production in forest stands constituted by deciduous plant species is directly influenced by the prevailing environmental conditions. In contrast, in forest ecosystems comprised by evergreen species, litterfall is generally less and does not reflect the inter-annual variation in primary productivity, but could be a good proxy for average primary productivity (Bellot et al., 1992; Lebret, Nys, \& Forgeard, 2001).

Litterfall is a fundamental process in ecosystem dynamics, it is indicative of ecological yield, and is of vital importance in soil formation and maintenance of soil fertility (Andivia et al., 2010; Nunes \& Garcia, 2015). The decomposition of the organic matter contributed by litterfall regulates nutrient and energy patterns in forest ecosystems (Facelli \& Pickett, 1991; Chapin, Matson, \& Mooney, 2002; Weltzin et al., 2005). In addition, litterfall is the main pathway and linkage for the return of minerals absorbed by plant roots to the soil, especially for macro(e.g. Ca, Mg, K, N and P) and micro-nutrients (e.g. Cu, Fe, Mn and Zn) (González-Rodríguez et al., 2013).

Furthermore, litterfall not only plays an important role in nutrient cycling, it also produces an organic layer that protects the soil from extreme temperature and moisture changes, prevents soil erosion, it is a source of food and host to multiple and complex microbial communities, it increases organic matter mineralization, improves soil physical and chemical properties, such as soil water availability, infiltration and nutrient absorption in forest ecosystems (Chapin, Matson, \& Mooney, 2002; Semwal et al., 2003; Wang et al., 2008). In addition, a number of studies have shown that microbial soil activity is an important determinant of the rate of recycling of plant mineral nutrients between organic and inorganic forms, i.e. between plants and the soil in which they grow (Domínguez, Aira, \& Gómez-Brandón, 2009; Celaya-Michel \& CastellanosVillegas, 2011).

Mexico, Brazil, Colombia and Indonesia, represent the most biologically megadiverse countries in the world; in particular, Mexico is also one of the most diverse countries with respect to pine or pine-oak forests, since about 55 Pinus species are found in the country, $85 \%$ of which are endemic (Mittermeier \& Mittermeier, 1992). Similarly, the Tamaulipan thorn scrub plant ecosystem in Mexico shows a great diversity of trees and shrubs, many of which play an important role in silvopastoral activities, a major socioeconomic productivity process in the agricultural system in northeastern Mexico (Foroughbakhch et al., 2009). However, land degradation and ecosystem alteration due to natural or anthropogenic disturbances have altered floristic plant composition and plant stand structure (Jiménez-Pérez et al., 2009), which in turn has affected net primary productivity in forest ecosystems by reducing the number of individuals of many species and consequently, has caused the loss of plant cover and, ultimately, species extinction or, 
as in other instances, the loss of soil fertility among other factors that alter ecosystem landscape (Vázquez \& Orozco, 1996).

Therefore, this region provides an opportunity to investigate litterfall production and nutrient return from forest and native vegetation to the soil in order to gain a better understanding of how to sustain and improve biomass productivity in response to changes in resource availability.

\section{OBJECTIVES}

The objective of this study was to assess monthly litterfall production and nutrient potential deposition through fallen leaves in three types of forest ecosystems of northeastern Mexico: 1) a pine forest, 2) an ecotone in a transition zone between a pine-oak forest and a piedmont shrubland, and 3) a thorn scrub in the Tamaulipan thorn-scrub vegetation community.

\section{MATERIALS AND METHODS}

\section{Study area}

The study was carried out at three sites located in the state of Nuevo Leon, Mexico. Site 1 "pine forest" was located at the Experimental Forest Research Station of the Universidad Autónoma de Nuevo Leon, in Iturbide County ( $24^{\circ} 43^{\prime} \mathrm{N}$; $99^{\circ} 52^{\prime} \mathrm{W} ; 1600 \mathrm{~m}$ a.s.l.). A pine (Pinus pseudostrobus Lindl.) forest mixed with deciduous trees comprises the vegetation community in this location, where soils are mainly rocky lutite or siltstone from the Upper Cretaceous; mean annual air temperature is $13.9^{\circ} \mathrm{C}$ and annual rainfall amounts to $639 \mathrm{~mm}$ on average. Site 2 "ecotone" was located in the ecotone of a Quercus spp. forest and a Piedmont shrubland ( $24^{\circ} 46^{\prime} \mathrm{N}$; $99^{\circ} 41^{\prime} \mathrm{W}$; $550 \mathrm{~m}$ a.s.l.) in Linares County. Average annual rainfall is approximately $755 \mathrm{~mm}$ and annual mean air temperature is $21{ }^{\circ} \mathrm{C}$ (González-Rodríguez et al., 2004). Site 3 “thorn scrub” was located at the Experimental Research Station at the Faculty of Forest Sciences of Universidad Autónoma de Nuevo León, also in Linares County (24 $47^{\prime} \mathrm{N}$; $99^{\circ} 32^{\prime} \mathrm{W} ; 350 \mathrm{~m}$ a.s.l.). The climate is subtropical and semiarid with a warm summer. Annual mean air temperature is $22.3{ }^{\circ} \mathrm{C}$ and average total annual precipitation is about $805 \mathrm{~mm}$ (González-Rodríguez et al., 2004). The vegetation in site three is known as Tamaulipan thorn scrub or subtropical thorn scrub woodlands (Secretaría de Programación y Presupuesto-Instituto Nacional de Geografía e Informática, 1986). In ecotone and thorn scrub sites, predominant soils are deep, dark-gray, lime-gray, lime-clay Vertisols with montmorillonite, which shrink and swell significantly in response to changes in soil moisture content.

\section{Vegetation of the study area}

The main type of vegetation in the three study sites is characterized by trees and shrubs formation, with dominant floristic elements $2 \mathrm{~m}$ to $7 \mathrm{~m}$ tall, mostly perennial thorny, with small, deciduous leaves. A total of 13710 individuals belonging to 28 families were registered (Ramírez-Lozano et al., 2013). The density for the pine forest, ecotone, and thorn scrub sites was 3850 individuals per hectare (ind ha-1), 3120, and 3360 ind ha-1, respectively. The sites with the lowest and highest plant cover were the pine forest (14 844 $\mathrm{m}^{2} \mathrm{ha}^{-1}$ ) and the ecotone (17 $\left.712 \mathrm{~m}^{2} \mathrm{ha}^{-1}\right)$. The most frequent species in the pine forest site were Quercus canbyi, Pinus pseudostrobus and Rhus pachyrrachis (with 11.9\%); while in the ecotone the most common species was: Havardia pallens $(9.9 \%)$ and in the thorn scrub Havardia pallens and Forestiera angustifolia (with 9.8\%) were the most abundant species. According to the Shannon index, the species richness documented for the pine forest, ecotone and thorn scrub are 1.64, 1.92 and 2.02 (Ramírez-Lozano et al., 2013). The most representative species in each study site are shown in table 1. The floristic description of the three sites has been reported by Ramírez-Lozano et al. (2013).

\section{Litterfall sampling}

Ten litter wooden canisters $\left(1.0 \mathrm{~m}^{2}\right)$ fitted with a nylon net bottom (1 $\mathrm{mm}$ mesh size), were randomly placed in an area of about $2500 \mathrm{~m}^{2}$ at each site for litterfall collection. Canister contents were collected at 15-day intervals from 
TABLE 1. Scientific names and family of identified plant species at each study site.

\begin{tabular}{|c|c|}
\hline \multicolumn{2}{|l|}{ Pine forest } \\
\hline Scientific name & Family \\
\hline Acacia farnesiana (L.) Willd. & Leguminosae \\
\hline Arbutus xalapensis Kunth & Ericaceae \\
\hline Croton incanus Kunth & Euphorbiaceae \\
\hline Cupressus arizonica Greene & Cupressaceae \\
\hline Juniperus flaccida Schltdl. & Cupressaceae \\
\hline Litsea pringlei Bartlett & Lauraceae \\
\hline Pinus pseudostrobus Lindl. & Pinaceae \\
\hline Quercus canbyi Trel. & Fagaceae \\
\hline Quercus glaucoides M. Martens \& Galeotti & Fagaceae \\
\hline Quercus laceyi Small & Fagaceae \\
\hline Rhus pachyrrhachis Hemsl. & Anacardiaceae \\
\hline \multicolumn{2}{|l|}{ Ecotone } \\
\hline Scientific name & Family \\
\hline Acacia farnesiana (L.) Willd. & Leguminosae \\
\hline Acacia rigidula Benth. & Leguminosae \\
\hline Berberis chochoco Schltdl. & Berberidaceae \\
\hline Bernardia myricifolia (Scheele) S. Watson & Euphorbiaceae \\
\hline Celtis pallida Torr. & Ulmaceae \\
\hline Cordia boissieri A. DC. & Boraginaceae \\
\hline Diospyros texana Scheele & Ebenaceae \\
\hline Ebenopsis ebano (Berland.) Barneby \& J.W. Grimes & Leguminosae \\
\hline Eysenhardtia polystachya (Ortega) Sarg. & Leguminosae \\
\hline Forestiera angustifolia Torr. & Oleaceae \\
\hline Fraxinus greggii A. Gray & Oleaceae \\
\hline Helietta parvifolia (A. Gray) Benth. & Rutaceae \\
\hline Quercus virginiana Mill. & Fagaceae \\
\hline \multicolumn{2}{|l|}{ Thorn scrub } \\
\hline Scientific name & Family \\
\hline Acacia berlandieri Benth. & Leguminosae \\
\hline Acacia rigidula Benth. & Leguminosae \\
\hline Bernardia myricifolia (Scheele) S. Watson & Euphorbiaceae \\
\hline Castela texana (Torr. \& A. Gray) Rose & Simaroubaceae \\
\hline Celtis pallida Torr. & Ulmaceae \\
\hline Cercidium macrum I.M. Johnst. & Leguminosae \\
\hline Condalia hookeri M.C. Johnst. & Rhamnaceae \\
\hline Diospyros texana Scheele & Ebenaceae \\
\hline Eysenhardtia polystachya (Ortega) Sarg. & Leguminosae \\
\hline Forestiera angustifolia Torr. & Oleaceae \\
\hline Havardia pallens (Benth.) Britton \& Rose & Leguminosae \\
\hline Helietta parvifolia (A. Gray) Benth. & Rutaceae \\
\hline Porlieria angustifolia (Engelm.) A. Gray & Zygophyllaceae \\
\hline Zanthoxylum fagara (L.) Sarg. & Rutaceae \\
\hline
\end{tabular}


January through December of 2009. Monthly litterfall production was quantitated by mixing the two samples taken 15 days apart. Litterfall contents were manually sorted into the following categories: leaves, reproductive structures (flowers, fruits and seeds), twigs, and miscellaneous residues (unidentified materials, fine plant tissue such as bark fragments, pieces of insect bodies or feces). Samples were dried to constant weight at $65^{\circ} \mathrm{C}$. Dry samples were ground in a Thomas Wiley mill (Thomas Scientific Apparatus, Model 3383, Swedesboro, New Jersey, USA) to pass $1.0 \mathrm{~mm}$ mesh sieve. The ground material was collected in previously labeled paper bags with corresponding data for subsequent chemical analysis. The leaves were considered as the main component of litterfall and as they were present throughout the study period.

\section{Mineral analysis}

Leaf litter samples from each canister were subjected to mineral analysis as follows. Mineral content was estimated by incinerating samples in a muffle oven at $550{ }^{\circ} \mathrm{C}$ for five hours. Ashes were digested in a solution containing $\mathrm{HCl}$ and $\mathrm{HNO}_{3}$ using the wet digestion technique (Cherney, 2000). Ca (oxide nitrous/acetylene flame), $\mathrm{K}, \mathrm{Mg}, \mathrm{Cu}, \mathrm{Fe}$, $\mathrm{Mn}$, and $\mathrm{Zn}$ (air/acetylene flame) content were estimated by atomic absorption spectrophotometry (Varian, Model SpectrAA-200, Mulgrave, Victoria, Australia); P was determined by spectrophotometry (Lambda 1A, PerkinElmer, Waltham, Massachusetts, USA) at $880 \mathrm{~nm}$ (Association of Official Analytical Chemists [AOAC], 1997). Mineral nutrient deposition at each site was calculated by multiplying leaf litter production of each sampling date by nutrient concentration for the same sampling date and site and adding them over the entire year; added values at each site were used as an estimate of the annual nutrient deposition. Leaf litter annual deposition values for $\mathrm{Ca}, \mathrm{K}, \mathrm{Mg}$ and $\mathrm{P}$ were used to estimate the leaf litter nutrient use efficiency (LLNUE) within each site; LLNUE was defined as the ratio of annual litter mass ( $\mathrm{kg}$ of leaf litter per hectare per year) to annual litter nutrient deposition ( $\mathrm{kg}$ of leaf nutrient per hectare per year) (Vitousek, 1982; Read \& Lawrence, 2003).

\section{Environmental variables}

Air temperature $\left({ }^{\circ} \mathrm{C}\right)$ was registered through $\mathrm{HOBO}$ sensors (H8 Family, Forestry Suppliers, Inc., Jackson, Mississippi, USA) at each study site every hour. Daily rainfall $(\mathrm{mm})$ was recorded during the experimental period using a HOBO sensor (Fig. 1).

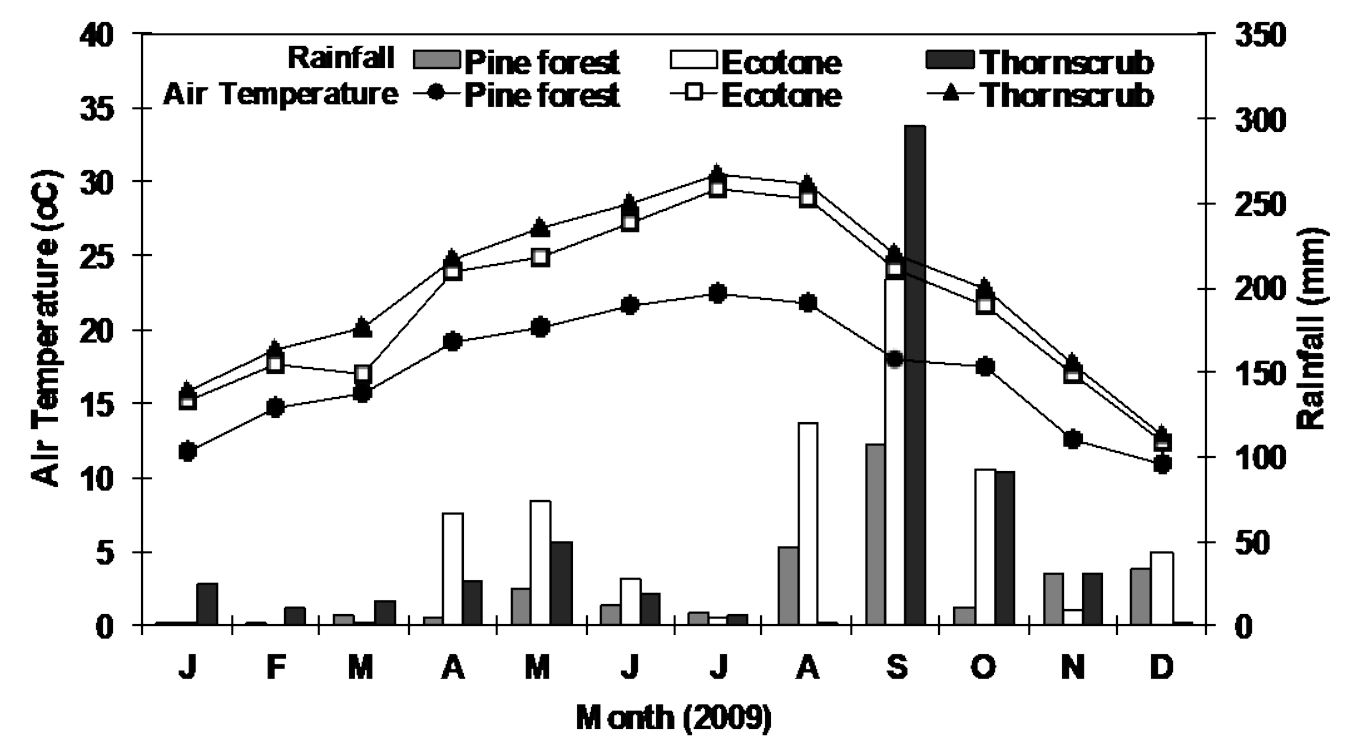

FIGURE 1. Monthly mean air temperature and rainfall in the study sites. 


\section{Statistical analysis}

Litterfall deposition data were subjected to one-way analysis of variance (Steel \& Torrie, 1980). Normal distribution and homogeneity of variances for each litter constituent and mineral content data were tested using the Kolmogorov-Smirnov, Shapiro-Wilk and Levene tests (Brown \& Forsythe, 1974; Steel \& Torrie, 1980), all of which provided enough evidence that litterfall and nutrient deposition data were non-normally distributed; therefore, the Kruskal-Wallis non parametric test was employed (Ott, 1993). Since ANOVA did not lend support to the assumption of equality of variances for most sampling dates, differences in litter deposition and nutrient deposition among sites were validated using the MannWhitney U non-parametric test with the Bonferroni's correction method at $P=0.05$ (Wackerly, Mendenhall, \& Scheaffer, 2002). The SPSS (Statistical Package for the Social Sciences) software package (standard released version 13.0 for Windows, SPSS Inc., Chicago, Illinois, USA) was used for all statistical analyses.

\section{Results}

\section{Litterfall production}

Total annual litterfall production and its components (leaves, reproductive structures, twigs, and miscellaneous) are shown in table 2. Total annual input varied from $706 \mathrm{~g}$ $\mathrm{m}^{-2}$ year $^{-1}$ in the ecotone to $483 \mathrm{~g} \mathrm{~m}^{-2}$ year $^{-1}$ in the pine forest. Leaves represented the main component of total annual litterfall deposition, ranging from $72.7 \%$ (thorn

TABLE 2. Annual deposition of litterfall components, leaf macro-nutrients ( $\mathrm{Ca}, \mathrm{K}, \mathrm{Mg}, \mathrm{P}$, and $\mathrm{N}$ ) and micro-nutrient (Cu, Fe, $\mathrm{Mn}$, and $\mathrm{Zn})$, and leaf macronutrient use efficiency in each site.

\begin{tabular}{|c|c|c|c|c|c|c|c|}
\hline \multirow[b]{2}{*}{ Annual deposition } & \multicolumn{3}{|c|}{ Sites } & \multirow[b]{2}{*}{$\begin{array}{c}\text { Mean } \pm \text { SEM } \\
g^{-2} \text { year }^{1}\end{array}$} & \multicolumn{3}{|c|}{ Comparison of means } \\
\hline & $\begin{array}{l}\text { 1) Pine forest } \\
\mathrm{g} \mathrm{m}^{-2} \text { year }^{\prime}\end{array}$ & 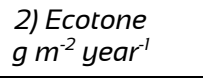 & $\begin{array}{l}\text { 3) Thornscrub } \\
\mathrm{g} \mathrm{m}^{-2} \text { year }^{\prime}\end{array}$ & & 1 vs 2 & 1 vs 3 & 2 vs 3 \\
\hline Leaves & $351.5 \pm 24.3$ & $466.8 \pm 28.9$ & $337.6 \pm 28.9$ & $385.3 \pm 18.7$ & 0.014 & 0.630 & 0.005 \\
\hline Twigs & $39.2 \pm 7.6$ & $111.2 \pm 11.3$ & $103.4 \pm 20.3$ & $84.6 \pm 9.8$ & $<0.001$ & 0.003 & 0.393 \\
\hline $\begin{array}{l}\text { Reproductive } \\
\text { structures }\end{array}$ & $27.0 \pm 6.2$ & $102.7 \pm 30.4$ & $37.5 \pm 7.4$ & $55.7 \pm 12.0$ & 0.008 & 0.217 & 0.035 \\
\hline Miscellaneous & $65.1 \pm 20.2$ & $25.1 \pm 3.7$ & $17.1 \pm 3.6$ & $35.8 \pm 7.7$ & 0.018 & $<0.001$ & 0.105 \\
\hline Total & $483.0 \pm 42.7$ & $706.0 \pm 32.7$ & $495.6 \pm 45.2$ & $561.5 \pm 29.5$ & $<0.001$ & 0.911 & 0.002 \\
\hline \multicolumn{8}{|l|}{ Macronutrient } \\
\hline $\mathrm{Ca}$ & $3.66 \pm 0.35$ & $11.47 \pm 1.36$ & $13.45 \pm 1.25$ & $9.53 \pm 0.99$ & $<0.001$ & $<0.001$ & 0.352 \\
\hline K & $0.98 \pm 0.08$ & $3.80 \pm 0.38$ & $3.04 \pm 0.46$ & $2.61 \pm 0.29$ & $<0.001$ & $<0.001$ & 0.352 \\
\hline $\mathrm{Mg}$ & $0.48 \pm 0.04$ & $1.29 \pm 0.14$ & $1.16 \pm 0.15$ & $0.98 \pm 0.09$ & $<0.001$ & $<0.001$ & 0.528 \\
\hline $\mathrm{N}$ & $2.69 \pm 0.2$ & $8.29 \pm 0.7$ & $7.17 \pm 0.6$ & $6.05 \pm 0.55$ & $<0.001$ & $<0.001$ & 0.226 \\
\hline$P$ & $0.14 \pm 0.01$ & $0.26 \pm 0.01$ & $0.23 \pm 0.02$ & $0.21 \pm 0.01$ & $<0.001$ & 0.001 & 0.481 \\
\hline \multicolumn{8}{|l|}{ Micronutrient } \\
\hline $\mathrm{Cu}$ & $0.94 \pm 0.09$ & $2.92 \pm 0.3$ & $1.98 \pm 0.2$ & $1.9 \pm 0.2$ & $<0.001$ & $<0.001$ & 0.043 \\
\hline $\mathrm{Fe}$ & $35.15 \pm 2.6$ & $61.30 \pm 6.4$ & $89.25 \pm 14.7$ & $61.9 \pm 6.6$ & 0.002 & $<0.001$ & 0.123 \\
\hline $\mathrm{Mn}$ & $27.70 \pm 7.9$ & $71.80 \pm 12.8$ & $16.22 \pm 2.7$ & $38.5 \pm 6.6$ & 0.003 & 0.314 & $<0.001$ \\
\hline $\mathrm{Zn}$ & $7.55 \pm 0.5$ & $7.75 \pm 0.8$ & $7.33 \pm 1.1$ & $7.5 \pm 0.5$ & 0.853 & 0.630 & 0.578 \\
\hline \multicolumn{8}{|l|}{$\begin{array}{l}\text { Macronutrient Use } \\
\text { Efficiency }\end{array}$} \\
\hline $\mathrm{Ca}$ & $99.2 \pm 5.9$ & $43.2 \pm 2.8$ & $25.9 \pm 1.6$ & $56.1 \pm 6.2$ & $<0.001$ & $<0.001$ & $<0.001$ \\
\hline K & $363.6 \pm 15.5$ & $131.3 \pm 11.1$ & $124.1 \pm 10.6$ & $206.3 \pm 21.8$ & $<0.001$ & $<0.001$ & 0.912 \\
\hline $\mathrm{Mg}$ & $729.5 \pm 24.2$ & $390.5 \pm 37.1$ & $308.5 \pm 22.7$ & $476.2 \pm 37.4$ & $<0.001$ & $<0.001$ & 0.165 \\
\hline$P$ & $2539.0 \pm 111.5$ & $1813.8 \pm 80.1$ & $1442.5 \pm 48.6$ & $1931.8 \pm 96.6$ & $<0.001$ & $<0.001$ & 0.001 \\
\hline $\mathrm{N}$ & $134.3 \pm 6.8$ & $58.6 \pm 3.3$ & $47.3 \pm 1.1$ & $80.1 \pm 7.5$ & $<0.001$ & $<0.001$ & 0.011 \\
\hline
\end{tabular}


scrub) to $66.1 \%$ (ecotone). Twigs represented $8.1 \%$ (pine forest), $15.7 \%$ (ecotone) and $20.8 \%$ (thorn scrub) of total litterfall. Reproductive structures (flowers, fruits and seeds) represented $5.5 \%, 14.5 \%$ and $5.5 \%$ of total litterfall deposition. Lastly, miscellaneous constituents were 13.4\%, $3.5 \%$ and $3.4 \%$, respectively, of total litterfall production.
Monthly leaf litter deposition varied significantly among sites only six months of the year; a similar pattern was observed for reproductive structures, twigs, miscellaneous and total litterfall (Table 3). Monthly litterfall deposition of leaves (Fig. 2a), twigs (Fig. 2b), reproductive structures (Fig. 2c), miscellaneous (Fig. 2d) and total

TABLE 3. Summary of the analyses of the Kruskal-Wallis test to detect significant differences among sites for litterfall components and total month deposition.

\begin{tabular}{|c|c|c|c|c|c|c|}
\hline \multirow[b]{2}{*}{ Month } & \multirow[b]{2}{*}{ Statistics } & \multicolumn{4}{|c|}{ Litterfall components } & \multirow[b]{2}{*}{ Total } \\
\hline & & Leaves & Twigs & $\begin{array}{l}\text { Reproductive } \\
\text { structures }\end{array}$ & Miscellaneous & \\
\hline \multirow[t]{2}{*}{ January } & $\chi^{2}$ & 11.365 & 2.217 & 8.152 & 18.088 & 6.366 \\
\hline & $P$ value & 0.003 & 0.330 & 0.017 & $<0.001$ & 0.041 \\
\hline \multirow[t]{2}{*}{ February } & $\chi^{2}$ & 14.627 & 18.795 & 8.276 & 8.968 & 13.169 \\
\hline & $P$ value & 0.001 & $<0.001$ & 0.016 & 0.011 & 0.001 \\
\hline \multirow[t]{2}{*}{ March } & $\chi^{2}$ & 12.924 & 14.617 & 3.120 & 3.254 & 13.386 \\
\hline & $P$ value & 0.002 & 0.001 & 0.210 & 0.196 & 0.001 \\
\hline \multirow[t]{2}{*}{ April } & $\chi^{2}$ & 3.259 & 10.934 & 4.679 & 8.828 & 6.475 \\
\hline & $P$ value & 0.196 & 0.004 & 0.096 & 0.012 & 0.039 \\
\hline \multirow[t]{2}{*}{ May } & $\chi^{2}$ & 6.320 & 14.480 & 1.210 & 1.866 & 0.302 \\
\hline & $P$ value & 0.042 & 0.001 & 0.546 & 0.393 & 0.860 \\
\hline \multirow[t]{2}{*}{ June } & $\chi^{2}$ & 5.437 & 12.364 & 9.084 & 15.347 & 1.208 \\
\hline & $P$ value & 0.066 & 0.002 & 0.011 & $<0.001$ & 0.547 \\
\hline \multirow[t]{2}{*}{ July } & $\chi^{2}$ & 5.128 & 13.272 & 9.246 & 9.363 & 6.968 \\
\hline & $P$ value & 0.077 & 0.001 & 0.010 & 0.009 & 0.031 \\
\hline \multirow[t]{2}{*}{ August } & $\chi^{2}$ & 3.595 & 18.126 & 4.121 & 9.298 & 4.880 \\
\hline & $P$ value & 0.166 & $<0.001$ & 0.127 & 0.010 & 0.087 \\
\hline \multirow[t]{2}{*}{ September } & $\chi^{2}$ & 8.508 & 11.948 & 12.212 & 10.098 & 8.578 \\
\hline & $P$ value & 0.014 & 0.003 & 0.002 & 0.006 & 0.014 \\
\hline \multirow[t]{2}{*}{ October } & $\chi^{2}$ & 3.285 & 12.364 & 6.227 & 1.350 & 8.434 \\
\hline & $P$ value & 0.193 & 0.002 & 0.044 & 0.509 & 0.015 \\
\hline \multirow[t]{2}{*}{ November } & $\chi^{2}$ & 2.519 & 3.468 & 5.151 & 11.399 & 3.089 \\
\hline & $P$ value & 0.284 & 0.177 & 0.076 & 0.003 & 0.213 \\
\hline \multirow[t]{2}{*}{ December } & $\chi^{2}$ & 7.992 & 10.426 & 4.495 & 16.237 & 8.849 \\
\hline & $P$ value & 0.018 & 0.005 & 0.106 & $<0.001$ & 0.012 \\
\hline
\end{tabular}



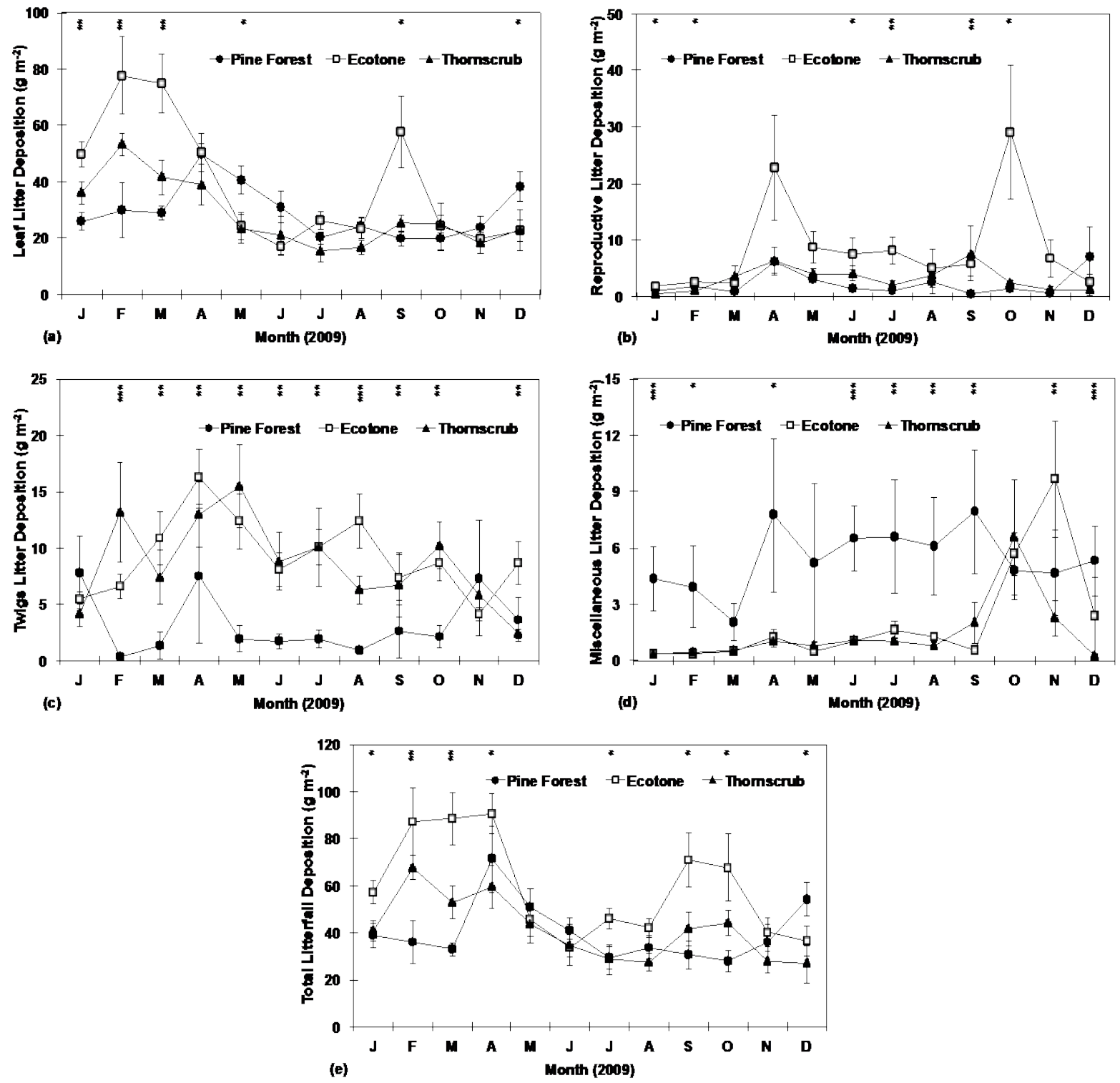

FiguRE 2. Monthly total nutrient deposition of leaves (a), reproductive structures (b), twigs (c), miscellaneous (d) and total litterfall (e) at research sites.

P-values of the Kruskal-Wallis test to detect significant differences among sites are shown at each sampling month within the graph ${ }^{*}=P \leq \mathrm{O} .05$; ${ }^{*}=$ $\left.P \leq 0.01 ;{ }^{* * *}=P \leq 0.001\right)$. Plotted values represent the mean \pm standard error $(n=10)$.

litterfall (Fig. 2e) showed significant differences in most months during the study period. In general, highest litterfall deposition was registered in the ecotone, followed by the thorn scrub and the pine forest. Leaf deposition in the pine forest ranged from $19.6 \mathrm{~g} \mathrm{~m}^{-2}$ (September) to 49.8 (April) $\mathrm{g} \mathrm{m}^{-2}$. Similarly, in the ecotone it ranged between $16.8 \mathrm{~g}$ $\mathrm{m}^{-2}$ (June) and $77.6 \mathrm{~g} \mathrm{~m}^{-2}$ (February), while in the thorn scrub the corresponding values varied from $15.5 \mathrm{~g} \mathrm{~m}^{-2}$ (July) to $53.2 \mathrm{~g} \mathrm{~m}^{-2}$ (February) (Fig. 2a). Twig deposition in the pine forest ranged from $0.4 \mathrm{~g} \mathrm{~m}^{-2}$ (January) to $7.8 \mathrm{~g} \mathrm{~m}^{-2}$ (January); and in the ecotone it varied from $4.1 \mathrm{~g} \mathrm{~m}^{-2}$ to 16.3 $\mathrm{g} \mathrm{m}^{-2}$ in November and April, respectively. In the thorn scrub twig deposition varied from $2.4 \mathrm{~g} \mathrm{~m}^{-2}$ in December to $15.5 \mathrm{~g} \mathrm{~m}^{-2}$ in May (Fig. 2b). In the pine forest, deposition of reproductive structures ranged from $0.5 \mathrm{~g} \mathrm{~m}^{-2}$ (September) to $6.6 \mathrm{~g} \mathrm{~m}^{-2}$ (December); in the ecotone it fluctuated 
between $1.8 \mathrm{~g} \mathrm{~m}^{-2}$ (January) and $29.0 \mathrm{~g} \mathrm{~m}^{-2}$ (October), and in the thorn scrub varied from $0.46 \mathrm{~g} \mathrm{~m}^{-2}$ in January to 7.5 $\mathrm{g} \mathrm{m}^{-2}$ in September (Fig. 2c). Miscellaneous deposition in the pine forest ranged from $3.9 \mathrm{~g} \mathrm{~m}^{-2}$ in February to $7.9 \mathrm{~g}$ $\mathrm{m}^{-2}$ in September. In the ecotone varied from $0.4 \mathrm{~g} \mathrm{~m}^{-2}$ (February) to $9.6 \mathrm{~g} \mathrm{~m}^{-2}$ (November), while in the thorn scrub it fluctuated from $0.2 \mathrm{~g} \mathrm{~m}^{-2}$ in December to $6.5 \mathrm{~g} \mathrm{~m}^{-2}$ in October (Fig. 2d). Total litterfall varied from $28.1 \mathrm{~g} \mathrm{~m}^{-2}$ (October) to $71.3 \mathrm{~g} \mathrm{~m}^{-2}$ (April) in the pine forest, from 33.5 $\mathrm{g} \mathrm{m}^{-2}$ (July) to $90.6 \mathrm{~g} \mathrm{~m}^{-2}$ (April) in the ecotone, and from $26.6 \mathrm{~g} \mathrm{~m}^{-2}$ (December) and $67.8 \mathrm{~g} \mathrm{~m}^{-2}$ (February) in the thorn scrub (Fig. 2e).

\section{Nutrient deposition}

Monthly leaf-litter potential nutrient deposition, including $\mathrm{Ca}, \mathrm{K}, \mathrm{Mg}, \mathrm{P}$ and $\mathrm{N}$ was significantly different among sampling sites (Table 4). In most months during the study, macronutrient ( $\mathrm{Ca}, \mathrm{Mg}, \mathrm{N}, \mathrm{K}$ and $\mathrm{P}$ ) deposition via leaf litter was significantly higher in the ecotone site, followed by the thorn scrub and pine forest sites (Fig. 3 a,b,c,d,e). In general, macronutrient deposition was higher during the winter months (January to march) than at any other time of the year. Annual Ca deposition was significantly higher in the thorn scrub compared to other sites, but annual $\mathrm{K}, \mathrm{Mg}$, $\mathrm{N}$ and $\mathrm{P}$ deposition was significantly higher in the ecotone, compared to the other sites (Table 2). Leaf macronutrient deposition in all sites ranked as follows: $\mathrm{Ca}>\mathrm{N}>\mathrm{K}>\mathrm{Mg}$ $>$ P. Total annual macronutrient deposition $(\mathrm{N}+\mathrm{Ca}+\mathrm{Mg}$ $+\mathrm{K}+\mathrm{P})$ in the pine forest, ecotone and thorn scrub sites amounted to 8.0, 25.1 and $25.1 \mathrm{~g} \mathrm{~m}^{-2}$ year ${ }^{-1}$, respectively. Leaf litter nutrient use efficiency (LLNUE) for $\mathrm{Ca}, \mathrm{Mg}, \mathrm{K}$, $\mathrm{N}$ and $\mathrm{P}$ ranked as follows: pine forest $>$ ecotone $>$ thorn scrub. Calcium LLNUE ranged from 25 to 99, potassium from 124 to 363, magnesium from 308 to 729 , phosphorus from 1442 to 2539 and nitrogen from 47 to 134 for thorn scrub and pine forest, respectively. Across sites, LLNUE was higher for $\mathrm{P}$ followed by $\mathrm{Mg}, \mathrm{K}, \mathrm{N}$, while it was lowest for Ca (Table 2).

Leaf-litter potential micronutrient $(\mathrm{Cu}, \mathrm{Fe}, \mathrm{Mn}$, and $\mathrm{Zn})$ deposition was significantly different among sites, particularly in winter (Table 4). Potential $\mathrm{Cu}, \mathrm{Fe}, \mathrm{Mn}$, and Zn deposition through fallen leaves (Fig. 4 a,b,c,d) was significantly different in most months, being higher in the ecotone site followed by the thorn scrub and pine forest. In general, micronutrient deposition was higher in winter, when leaf litter deposition was also higher than in any other season (Fig. 2a). The annual potential deposition of $\mathrm{Cu}, \mathrm{Fe}$ and $\mathrm{Mn}$ was significantly higher in the ecotone than in the pine forest or the thorn scrub (Table 2). However, potential deposition of leaf $\mathrm{Zn}$ was not different $(\mathrm{P}>0.05)$ among sites. Leaf micronutrient deposition ranked as follows: $\mathrm{Fe}$ $>\mathrm{Mn}>\mathrm{Zn}>\mathrm{Cu}$ (Table 2). Total annual micronutrient deposition $(\mathrm{Cu}+\mathrm{Mn}+\mathrm{Fe}+\mathrm{Zn})$ was $143.7 \mathrm{mg} \mathrm{m}^{-2}$ year $^{-1}$, $114.8 \mathrm{mg} \mathrm{m}^{-2}$ year-1 and $71.3 \mathrm{mg} \mathrm{m}^{-2}$ year-1 for the ecotone, thorn scrub and pine forest, respectively.

\section{DISCUSSION}

\section{Litterfall}

The highest and lowest total annual litterfall measurements were recorded in the ecotone and the pine forest, respectively. A similar trend was observed for twigs and reproductive structures; in contrast, miscellaneous depositions were higher at the Pinus forest plant community (Table 2). These observations are similar to litterfall values previously reported in studies conducted in the same region (López-Hernández et al., 2013) and in the microphyllous desert scrubland at northeastern Mexico (GonzálezRodríguez et al., 2013); however, lower quantities (202.7 g $\mathrm{m}^{-2}$ year ${ }^{-1}, 100.2 \mathrm{~g} \mathrm{~m}^{-2}$ year $^{-1}$ and $35.2 \mathrm{~g} \mathrm{~m}^{-2}$ year-1) were recorded by Martínez-Yrizar, Nuñez, Miranda, and Búrquez (1999) in the Sonora Desert vegetation of northern Mexico. In this study, leaves represented the major component of litterfall; $66 \%$ to $72 \%$. These percentages are within the ranges reported by GonzálezRodríguez et al. (2011), González-Rodríguez et al. (2013) and López-Hernández et al. (2015) for these ecosystems. Santa-Regina (2000), Santa-Regina and Tarazona (2001) and Caritat, García, Lapeña, and Vilar (2006) reported that the leaf component represented $50 \%$ to $80 \%$ of all litterfall in pine and pine-oak forests. Apparently, the amount of 
leaves produced with respect to the total plant biomass that falls on the ground becomes subject to mineralization processes that eventually recycle nutrients present in dead plant tissues back into the soil and could depend on the stage of development and age of the plant. Maximum contribution to forest litter seems to occur concomitantly with highest rates of carbon assimilation and respiration during periods of high litterfall production (MartínezAlonso et al., 2007). Moreover, the observed differences in leaf fall at the ecotone ecosystem, relative to the Pinus forest ecosystem, could relate to the continuous shedding of leaves by abundant deciduous plant species in the first case. A much studied morpho-physiological adaptive mechanism in plants of the Tamaulipan thorn scrub ecosystem to cope with severe water deficit and high temperature, and thus prevent excessive water loss through transpirational flux and extreme plant tissue dehydration, could relate to litterfall deposition (González-Rodríguez et al., 2004).

TABLE 4. Summary of the Kruskal-Wallis test to detect significant differences among sites for macro- (Ca, $\mathrm{K}, \mathrm{Mg}, \mathrm{P}$ and $\mathrm{N})$ and micronutrient (Cu, Fe, $\mathrm{Mn}$, and $\mathrm{Zn})$ deposition.

\begin{tabular}{|c|c|c|c|c|c|c|c|c|c|c|}
\hline \multirow[b]{2}{*}{ Month } & \multirow[b]{2}{*}{ Statistic } & \multicolumn{9}{|c|}{ Nutrient } \\
\hline & & $\mathrm{Ca}$ & $K$ & $M g$ & $P$ & $N$ & $\mathrm{Cu}$ & $\mathrm{Fe}$ & $M n$ & $Z n$ \\
\hline \multirow[t]{2}{*}{ January } & $\chi^{2}$ & 19.935 & 18.449 & 18.243 & 10.888 & 15.719 & 16.717 & 14.356 & 13.427 & 5.084 \\
\hline & $P$ value & $<0.001$ & $<0.001$ & $<0.001$ & 0.004 & $<0.001$ & $<0.001$ & 0.001 & 0.001 & 0.079 \\
\hline \multirow[t]{2}{*}{ February } & $\chi^{2}$ & 17.701 & 19.425 & 13.985 & 15.564 & 14.999 & 15.246 & 13.350 & 11.365 & 2.108 \\
\hline & $P$ value & $<0.001$ & $<0.001$ & 0.001 & $<0.001$ & 0.001 & $<0.001$ & 0.001 & 0.003 & 0.348 \\
\hline \multirow[t]{2}{*}{ March } & $\chi^{2}$ & 19.419 & 20.286 & 17.654 & 15.037 & 20.101 & 19.173 & 14.759 & 8.988 & 2.821 \\
\hline & $P$ value & $<0.001$ & $<0.001$ & $<0.001$ & 0.001 & $<0.001$ & $<0.001$ & 0.001 & 0.011 & 0.244 \\
\hline \multirow[t]{2}{*}{ April } & $\chi^{2}$ & 11.430 & 7.357 & 7.404 & 5.739 & 11.530 & 10.738 & 1.866 & 13.915 & 5.739 \\
\hline & $P$ value & 0.003 & 0.025 & 0.025 & 0.057 & 0.003 & 0.005 & 0.393 & 0.001 & 0.057 \\
\hline \multirow[t]{2}{*}{ May } & $\chi^{2}$ & 5.004 & 6.730 & 0.705 & 0.405 & 4.137 & 1.425 & 3.177 & 9.014 & 6.676 \\
\hline & $P$ value & 0.082 & 0.035 & 0.703 & 0.817 & 0.126 & 0.490 & 0.204 & 0.011 & 0.036 \\
\hline \multirow[t]{2}{*}{ June } & $\chi^{2}$ & 4.710 & 3.479 & 0.379 & 0.163 & 1.373 & 5.978 & 1.644 & 6.604 & 4.408 \\
\hline & $P$ value & 0.095 & 0.176 & 0.827 & 0.922 & 0.503 & 0.050 & 0.440 & 0.037 & 0.110 \\
\hline \multirow[t]{2}{*}{ July } & $\chi^{2}$ & 11.166 & 14.524 & 13.195 & 9.742 & 13.990 & 16.297 & 2.563 & 18.356 & 4.137 \\
\hline & $P$ value & 0.004 & 0.001 & 0.001 & 0.008 & 0.001 & $<0.001$ & 0.278 & $<0.001$ & 0.126 \\
\hline \multirow[t]{2}{*}{ August } & $\chi^{2}$ & 12.480 & 17.290 & 12.560 & 4.160 & 13.822 & 14.835 & 2.728 & 15.120 & 7.310 \\
\hline & $P$ value & 0.002 & $<0.001$ & 0.002 & 0.125 & 0.001 & 0.001 & 0.256 & 0.001 & 0.026 \\
\hline \multirow[t]{2}{*}{ September } & $\chi^{2}$ & 18.289 & 19.094 & 19.636 & 18.774 & 19.295 & 21.311 & 17.861 & 21.154 & 5.345 \\
\hline & $P$ value & $<0.001$ & $<0.001$ & $<0.001$ & $<0.001$ & $<0.001$ & $<0.001$ & $<0.001$ & $<0.001$ & 0.069 \\
\hline \multirow[t]{2}{*}{ October } & $\chi^{2}$ & 12.294 & 7.837 & 9.726 & 10.640 & 14.895 & 4.319 & 8.991 & 5.236 & 6.434 \\
\hline & $P$ value & 0.002 & 0.020 & 0.008 & 0.005 & 0.001 & 0.115 & 0.011 & 0.073 & 0.040 \\
\hline \multirow[t]{2}{*}{ November } & $\chi^{2}$ & 4.253 & 4.483 & 1.435 & 0.147 & 4.865 & 2.290 & 1.241 & 8.226 & 2.387 \\
\hline & $P$ value & 0.119 & 0.106 & 0.488 & 0.929 & 0.088 & 0.318 & 0.538 & 0.016 & 0.303 \\
\hline \multirow[t]{2}{*}{ December } & $\chi^{2}$ & 4.601 & 0.095 & 0.134 & 1.427 & 4.028 & 2.775 & 3.585 & 4.625 & 7.649 \\
\hline & $P$ value & 0.100 & 0.953 & 0.935 & 0.490 & 0.133 & 0.250 & 0.167 & 0.099 & 0.022 \\
\hline
\end{tabular}



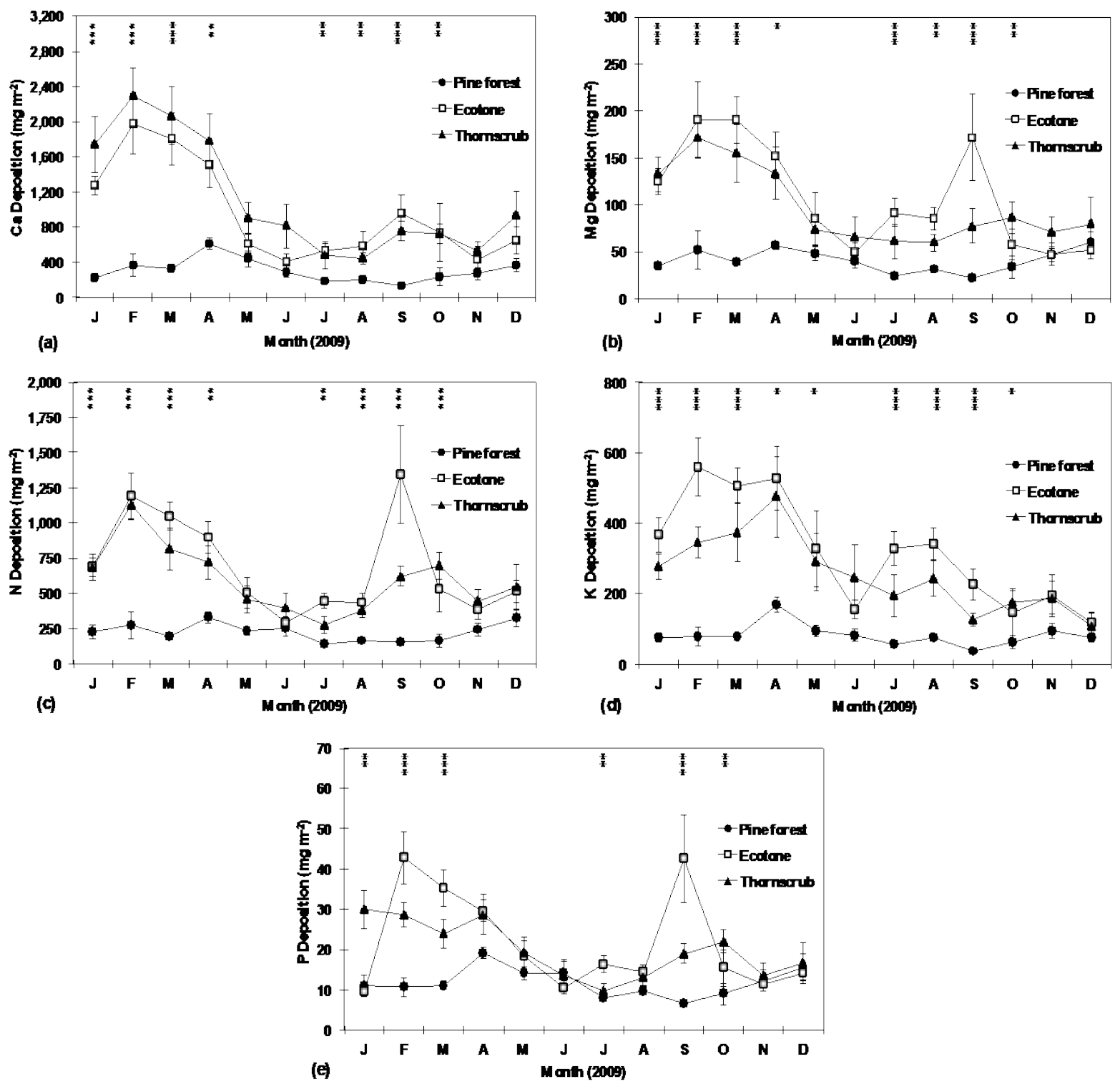

FigurE 3. Monthly deposition of $\mathrm{Ca}(\mathrm{a}), \mathrm{Mg}(\mathrm{b}), \mathrm{N}(\mathrm{c}), \mathrm{K}(\mathrm{d})$ and $\mathrm{P}$ (e) through leaf litter at research sites.

$P$-values of the Kruskal-Wallis test to detect significant differences among sites are shown at each sampling month within the graph $\left(^{*}=P \leq 0.05\right.$ $\left.{ }^{* *}=P \leq 0.01 ; * * *=P \leq 0.001\right)$. Plotted values represent the mean \pm standard error $(n=10)$.

The differences in production and composition of litterfall among sites may be due to variations in plant species composition of the vegetation community at each site (Table 1), as this clearly reflects diverse plant phenology patterns. The pine forest was a mixed forest plant community comprised of pine trees (Pinus pseudostrobus Lindl.) and several deciduous trees. At the ecotone site, the vegetation is constituted by Quercus spp. and diverse species of the Piedmont shrubland, while in the thorn scrub, the vegetation corresponds to the Tamaulipan thorn scrub or subtropical thorn scrub woodlands. In addition, prevailing climatic conditions registered at each study area influenced litterfall deposition; in general, higher litterfall deposition occurred in the months with lower rainfall and lower temperatures (Fig. 1).

Similar to the findings reported herein, several researchers have reported that litter production in forest ecosystems is determined by climatic conditions, species 

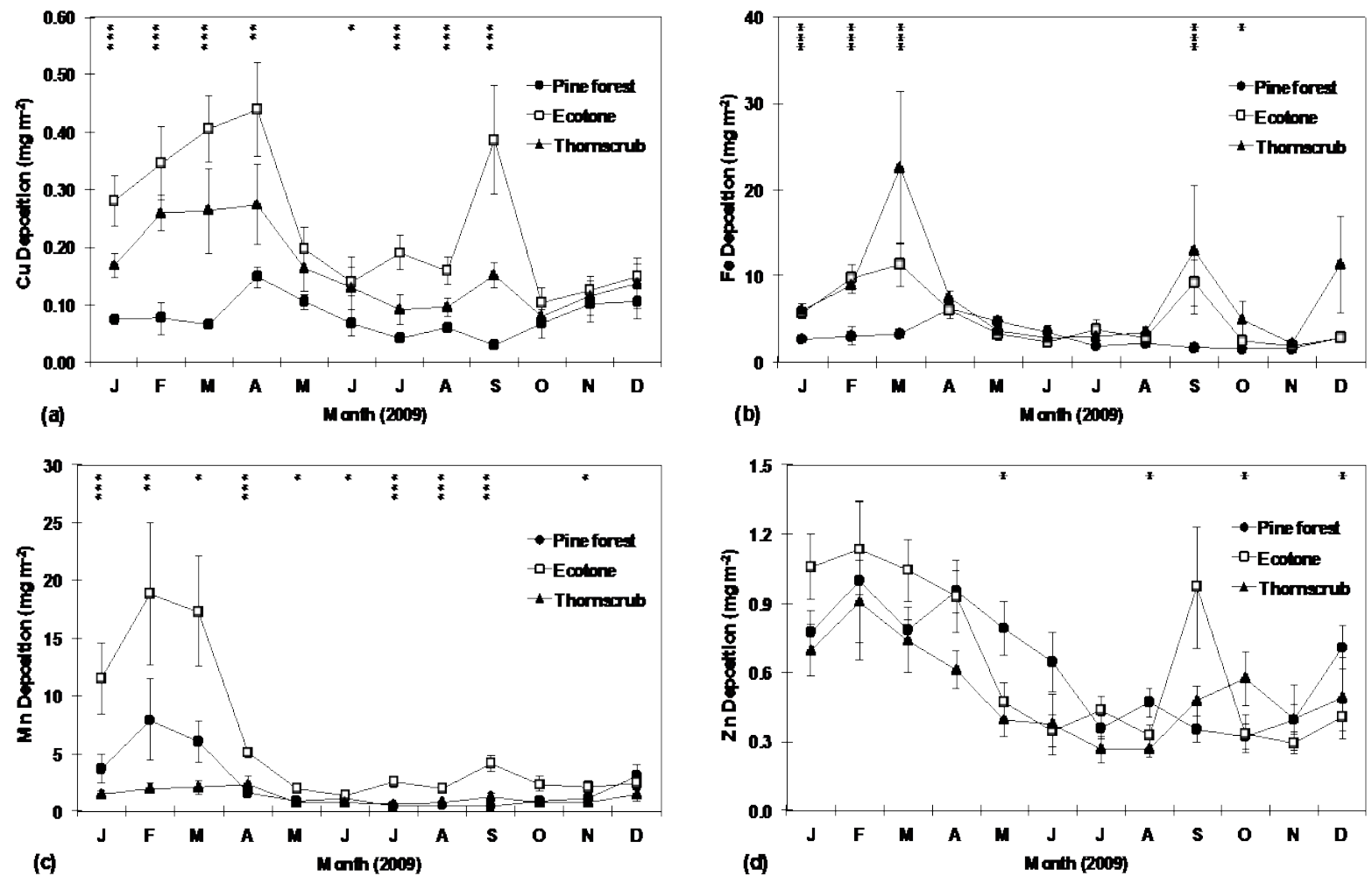

Figure 4. Monthly deposition of $\mathrm{Cu}(\mathrm{a}), \mathrm{Fe}(\mathrm{b}), \mathrm{Mn}(\mathrm{c})$, and $\mathrm{Zn}$ (d) through leaf litter at research sites.

$P$-values of the Kruskal-Wallis test to detect significant differences among sites are shown at each sampling month within the graph $\left(^{*}=P \leq 0.05 ; * *=P \leq\right.$ $\left.0.01 ;{ }^{* * *}=P \leq 0.001\right)$. Plotted values represent the mean \pm standard error $(\mathrm{n}=10)$.

composition, and successional stage (Haase, 1999; Sundarapandian \& Swamy, 1999; González-Rodríguez et al., 2013; López-Hernández et al., 2015). Similar responses were reported by González-Rodríguez et al. (2013) and LópezHernández et al. (2013) in studies carried out in microphyllous vegetation and in a thorn scrub, respectively. In agreement with our findings, Bellot et al. (1992), Lebret, Nys, and Forgeard (2001). Caritat, García, Lapeña, and Vilar (2006) and Martinez-Alonso et al. (2007) reported that the dynamics of productivity of aerial biomass it is very dependent on the variability of climatic conditions between different years; therefore, it is difficult to establish a general pattern of litterfall production and composition in short periods, in areas with great climatic variability.

\section{Mineral deposition}

Regardless of location, deposition of macronutrients through litterfall occurred in the following order: $\mathrm{Ca}>\mathrm{N}$
$>\mathrm{K}>\mathrm{Mg}>\mathrm{P}$. Similar values have been reported for the Tamaulipan thorn scrub vegetation (González-Rodríguez et al., 2011; López-Hernández et al., 2013), for a microphyllous desert vegetation, (González-Rodríguez et al., 2013), for a wet forest community in Colombia (Del Valle-Arango, 2003), for a natural forest in subtropical China (Yang, Wang, Kellomäki, \& Zhang, 2006), and for legume agroforestry species (Sileshi \& Mafongoya, 2007).

The deposition of micronutrients through litterfall observed in this study $(\mathrm{Fe}>\mathrm{Mn}>\mathrm{Zn}>\mathrm{Cu}$ ) was similar to those reported by González-Rodríguez et al. (2013) and López-Hernández et al. (2013) in studies carried in microphyllous vegetation and in a thorn scrub in northeastern Mexico, respectively, and by Andivia et al. (2010) in a Quercus suber vegetation in the Mediterranean region in Spain.

In the present study, macronutrient use efficiency was significantly higher at the pine forest than at the other sites. 
In this regard, it is tempting to speculate that woody plant species from the pine forest could be more efficient in nutrient translocation than plant species from the other sites, since annual deposition levels of $\mathrm{Ca}, \mathrm{K}, \mathrm{Mg}, \mathrm{P}$ y N, observed in leaf litter from the pine forest were lower compared with the ecotone and thorn scrub sites (Table 2). Although P deposition via leaf litterfall was lower than for other macronutrients, its nutrient use efficiency was relatively higher than that for $\mathrm{Ca}, \mathrm{N}, \mathrm{K}$ or $\mathrm{Mg}$. A similar pattern has been previously documented in different ecosystems (Del Valle-Arango, 2003; Swamy, Kushwaha, \& Puri, 2004; Safou-Matondo, Deleporte, Laclau, \& Bouillet, 2005; González-Rodríguez et al., 2011; López-Hernández et al., 2013). It has been argued that $P$ maybe translocated to other plant structures before leaf senescence to participate in the development of new plant structures or physiological processes (Palma et al., 2000).

In contrast, the low levels of $\mathrm{N}$ in the pine forest, compared with the ecotone or the thorn scrub, could be associated with the capability of symbiotic nitrogen fixation of leguminous plant species observed at the study sites, since at the pine forest, plant species belonging to the Leguminosae family represented only $4 \%$ of total species richness, while in the ecotone and thorn scrub sites, leguminous species represented about $20 \%$ and $25 \%$, of the vegetation community, respectively. Therefore, the efficiency in $\mathrm{N}$ use from litterfall was determined by the presence of legume plant species at the study sites. This agrees with Rothe and Binkley (2001) and Forrester, Bauhus, and Cowie (2005), who reported that in mixed forest stands, $\mathrm{N}$-fixing species increased and improved nutrient cycling through litterfall relative to stands containing fewer $\mathrm{N}$-fixing species.

In general, higher deposition of leaves (winter months) coincided with higher potential in nutrient deposition in the three study sites. In addition, higher rainfall at the ecotone and thorn scrub during the study period (Fig. 1) may be involved in the increase of nutrient deposition in those sites, as compared to the pine forest (Ramírez-Lozano et al., 2013). Increase in mineral contents due to higher rainfall has also previously reported by Ramírez-Lozano et al.
(2010), who evaluated the mineral profile of native shrubs in northeastern Mexico.

Although in this study, nutrient content and deposition were not measured in other litter constituents such as twigs or reproductive structures, other studies have demonstrated that the nutrient content can be higher in other components than in leaves (Cantú-Silva et al., 2013) but with lower annual depositions.

\section{CONCLUSIONS}

This research aimed to contribute to our understanding of the role played by seasonal mineral nutrient cycling from litterfall back to the soil in support of the sustainability at three different forest ecosystems: a Pinus forest (Pine forest), a Quercus forest and the Piedmont thorn scrub (Ecotone) and a Tamaulipan thorn scrub woodland (Thorn scrub). Deposition of litterfall and its components varied among both, sites and months. The ecotone registered the highest total deposition, followed by the thorn scrub and the pine forest. Winter months showed the highest deposition during the year. Deposition of leaves was highest, followed by twigs and reproductive structures, while miscellaneous was the lowest proportion of total litterfall regardless of site. In general, leaf Ca was deposited to larger amounts, followed by $\mathrm{N}, \mathrm{K}, \mathrm{Mg}$ and $\mathrm{P}$. The $\mathrm{P}$ deposition in leaves had higher nutrient use efficiency than other macronutrients. Differences in potential for nutrient cycling to the soil may relate to differences among sites with respect to climate, plant composition of vegetation communities, litterfall nutrient composition and soil microbial activity. Since study has been conducted for one year, intern-annual variation in litterfall production and nutrient returns should be considered.

\section{ACKNOWLEDGEMENTS}

We gratefully acknowledge technical assistance provided by Elsa Dolores González Serna and Manuel Hernández Charles. The authors also appreciate and acknowledge the landowner of the ecotone site for providing the necessary assistance to establish the experimental plot. We wish to thank two anonymous referees for critical reading of our 
manuscript and for their constructive comments, which helped to improve the manuscript. This research was partially funded by Universidad Autónoma de Nuevo León (PAICYT, grant CT259-15) and by the Consejo Nacional de Ciencia y Tecnología (CONACYT, grant 250732).

\section{REFERENCES}

Andivia, E., Fernández, M., Vázquez-Piqué, J., González-Pérez, A., \& Tapias, R. (2010). Nutrient return from leaves and litterfall in a Mediterranean cork oak (Quercus suber L.) forest in southwestern Spain. European Journal of Forest Research, 129(1), 5-12. https://doi.org/10.1007/s10342-009-0274-6

Association of Official Analytical Chemists [AOAC] (1997). Official Methods of Analysis (16th ed.). Washington, DC: AOAC.

Bellot, J., Sánchez, J., Lledó, M., Martínez, P., \& Escarré, A. (1992). Litterfall as a measure of primary production in Mediterranean holm-oak forest. Plant Ecology, 99(1), 69-76. doi: 10.1007/978-94017-2836-2 6

Brown, M. B. \& Forsythe, A. B. (1974). Robust tests for the equality of variances. Journal American Statistical Association, 69(346), 364-367.

Cantú-Silva, I., Sánchez-Castillo, L. R. M., González-Rodríguez, H., Kubota, T., Gómez-Meza, M. V., \& Domínguez-Gómez, T. G. (2013). Retorno potencial de nutrimentos por componentes secundarios de la hojarasca en comunidades vegetales de Nuevo León. Revista Mexicana de Ciencias Forestales, 4(17), 138-155. doi: $\underline{10.29298 / \text { rmcf.v4i17.427 }}$

Caritat, A., García, B. E., Lapeña, R., \& Vilar, L. (2006). Litter production in a Quercus suber forest of Montseny (NE Spain) and its relationship to meteorological conditions. Annals of Forest Science, 63, 791-800. doi: $10.1051 /$ forest:2006061

Celaya-Michel, H. \& Castellanos-Villegas, A. E. (2011). Mineralización de nitrógeno en el suelo de zonas áridas y semiáridas. Terra Latinoamericana, 29(3), 343-356.

Chapin, F., Matson, P., \& Mooney, H. (2002). Principles of terrestrial ecosystem ecology. New York, USA: Springer.

Cherney, D. J. R. (2000). Characterization of forages by chemical analysis. In: D. I. Givens, E. Owen, R. F. E. Axford, \& H. M. Omed (Eds.), Forage evaluation in ruminant nutrition (pp. 281-300). Wallingford, UK: CABI Publishing.

Del Valle-Arango, J. I. (2003). Cantidad, calidad y nutrientes reciclados por la hojarasca fina en bosques pantanosos del Pacífico Sur Colombiano. Interciencia, 28(8), 443-449.
Domínguez, J., Aira, M., \& Gómez-Brandón, M. (2009). El papel de las lombrices de tierra en la descomposición de la materia orgánica y el ciclo de nutrientes. Revista Ecosistemas, 18(2), 20-31.

Facelli, J. M. \& Pickett, S. (1991). Plant litter: light interception and effects on an old-field plant community. Ecology, 72(3), 1024-1031. doi: $10.2307 / 1940602$

Foroughbakhch, R., Hernández-Piñero, J. L., Alvarado-Vázquez, M. A., Céspedes-Cabriales, E., Rocha-Estrada, A., \& Cárdenas-Ávila, M. L. (2009). Leaf biomass determination on woody shrub species in semiarid zones. Agroforestry Systems, 77, 181-192. doi: $10.1007 / \mathrm{s} 10457-008-9194-6$

Forrester, D. I., Bauhus, J., \& Cowie, A. L. (2005). Nutrient cycling in a mixed-species plantation of Eucalyptus globulus and Acacia mearnsii. Canadian Journal of Forest Research, 35(12), 2942-2950. doi: $\underline{10.1139 / \mathrm{x} 05-214}$

González-Rodríguez, H., Cantú-Silva, I., Gómez-Meza, M. V., \& Ramírez-Lozano, R. G. (2004). Plant water relations of thorn scrub shrub species, Northeastern Mexico. Journal of Arid Environments, 58(4), 483-503. doi: 10.1016/j.jaridenv.2003.12.001

González-Rodríguez, H., Cantú-Silva, I., Ramírez-Lozano, R. G., Gómez-Meza, M. V., Domínguez-Gómez, T. G., Bravo-Garza, J., \& Maiti, R. K. (2008). Spatial and seasonal litterfall deposition pattern in the Tamaulipan thornscrub, Northeastern Mexico. International Journal of Environment, Agriculture and Biotechnology, 1(4), 177-181.

González-Rodríguez, H., Domínguez-Gómez, T. G., Cantú-Silva, I., Gómez-Meza, M. V., Ramírez-Lozano, R. G., Pando-Moreno, M., \& Fernández. C. J. (2011). Litterfall deposition and leaf litter nutrient return in different locations at Northeastern Mexico. Plant Ecology, 212(10), 1747-1757. https://doi.org/10.1007/s11258-011-9952-9

González-Rodríguez, H., Ramírez-Lozano, R. G., Cantú-Silva, I., Gómez-Meza, M. V., Cotera-Correa, M., Carrillo-Parra, A., \& Marroquín-Castillo, J. J. (2013). Litterfall production and nutrient returns through leaves in a microphyllous desert scrubland, northeastern Mexico. Revista Chapingo Serie Ciencias Forestales, 19, 249-262. doi: 10.5154/r.rchscfa.2012.08.048

Haase, R. (1999). Litterfall and nutrient return in seasonally flooded and non-flooded forest of the Pantanal, Mato Grosso, Brazil. Forest Ecology and Management, 117(1-3), 129-147. https://doi.org/10.1016/S0378-1127(98)00477-0

Jiménez-Pérez, J., Alanís-Rodríguez, E., Aguirre-Calderón, O., PandoMoreno, M., \& González-Tagle, M. (2009). Análisis sobre el efecto del uso del suelo en la diversidad estructural del matorral espinoso tamaulipeco. Madera y Bosques, 15(3), 5-20. doi: $\underline{10.21829 / \text { myb.2009.1531183 }}$ 
Lebret, M., Nys, C., \& Forgeard, F. (2001). Litter production in an Atlantic beech (Fagus sylvatica L.) time sequence. Annals of Forest Science, 58, 755-768. doi: 10.1051/ forest:2001161

López-Hernández, J. M., González-Rodríguez, H., Ramírez-Lozano, R. G., del Valle-Arango, J. I., Cantú-Silva, I., Pando-Moreno, M., Estrada-Castillón, A. E., \& Gómez-Meza, M. V. (2015). Producción de hojarasca y depósito potencial de nutrientes de las hojas en el Matorral Espinoso Tamaulipeco. Revista Mexicana de Ciencias Forestales, 6(30), 74-89. doi: 10.29298/rmcf.v6i30.209

López-Hernández, J. M., González-Rodríguez, H., Ramírez-Lozano, R. G., Cantú-Silva, I., Gómez-Meza, M. V., Pando-Moreno, M., \& Estrada-Castillón, A. E. (2013). Producción de hojarasca y retorno potencial de nutrientes en tres sitios del Estado de Nuevo León, México. Polibotánica, 35, 65-78.

Martín, A., Gallardo, J. F., \& Santa-Regina, I. (1996). Aboveground litter production and bioelement potential return in an evergreen oak (Quercus rotundifolia) woodland near Salamanca (Spain). Annals of Forest Science, 53(4), 811-818. doi:10.1051/forest:19960402

Martínez-Alonso, C., Valladares., F., Camarero, J. J., López-Arias, M., Serrano, M., \& Rodríguez, J. A. (2007). The uncoupling of secondary growth, cone and litter production by intradecadal climatic variability in a Mediterranean scots pine forest. Forest Ecology and Management, 253(1), 19-29. doi: $\underline{10.1016 / j \text {.foreco.2007.06.043 }}$

Martínez-Yrizar, A., Nuñez, S., Miranda, H., \& Búrquez, A. (1999). Temporal and spatial variation of litter production in Sonora Desert communities. Plant Ecology, 145(1), 37-48. doi: 10.1023/A:1009896201047

Mittermeier, R. \& Mittermeier, C. G. (1992). La importancia de la diversidad biológica de México, En: J. Sarukhán and R. Dirzo (comps.), México ante los retos de la biodiversidad (pp. 63-73). México: Conabio.

Nunes, F. P. \& Garcia, Q. S. (2015). Adequacy assessment of mathematical models in the dynamics of litter decomposition in a tropical forest Mosaic Atlantic, in southeastern Brazil. Brazilian Journal of Biology, 75(2), 268-272. http://dx.doi.org/010.1590/1519-6984.08413

Oelbermann, M. \& Gordon, A. M. (2000). Quantity and quality of autumnal litterfall into a rehabilitated agricultural stream. Journal of Environmental Quality, 29, 603-610. doi: 10.2134/jeq2000.00472425002900020031x

Ott, L. (1993). An introduction to statistical methods and data analysis (2nd ed.). Boston, Massachusetts, USA: Duxbury Press.

Palma, R. M., Defrieri, R. L., Tortarolo, M. F., Prause, J., \& Gallardo, J. F. (2000). Seasonal changes of bioelements in the litter and their potential return to green leaves in four species of the Argentine subtropical forest. Annals of Botany, 85(2), 181-186. doi: 10.1006/anbo.1999.1005

Pavón, N. P., Briones, O., \& Flores-Rivas, J. (2005). Litterfall production and nitrogen content in an intertropical semi-arid Mexican scrub. Journal of Arid Environments, 60(1), 1-13. ㅇi: $\underline{10.1016 / \text { i.jaridenv.2004.03.004 }}$

Prause, G. J., Arce, C., \& Angeloni, P. N. (2003). Variación mensual en el aporte de hojas de cuatro especies forestales nativas del Parque Chaqueño Húmedo (Argentina). Revista de Ciencias ForestalesQuebracho, 10, 39-45.

Ramírez-Lozano, R. G., Domínguez-Gómez, T. G., GonzálezRodríguez, H., Cantú-Silva, I., Gómez-Meza, M. V., SarquísRamírez, J. I., \& Jurado, E. (2013). Composición y diversidad de la vegetación en cuatro sitios del noreste de México. Madera y Bosques, 19(2), 59-72. doi: 10.21829/myb.2013.192340

Ramírez-Lozano, R. G., González-Rodríguez, H., Gómez-Meza, M. V., Cantú-Silva, I., \& Uvalle-Sauceda, J. I. (2010). Spatio-temporal variations of macro and trace mineral contents in six native plants consumed by ruminants at northeastern Mexico. Tropical and Subtropical Agroecosystems, 12(2), 267-281.

Read, L. \& Lawrence, D. (2003). Recovery of biomass following shifting cultivation in dry tropical forests of the Yucatan. Ecological Applications, 13(1), 85-97. doi: 10.1890/10510761(2003)013[0085:ROBFSC]2.0.CO;2

Roig, S., del Río, M., Canellas, I., \& Montero, G. (2005). Litter fall in Mediterranean Pinus pinaster Ait. stands under different thinning regimes. Forest Ecology and Management, 206(1-3), 179-190. doi: $\underline{10.1016 / \text { ij.foreco.2004.10.068 }}$

Rothe, A. \& Binkley, D. (2001). Nutritional interactions in mixed species forests: a synthesis. Canadian Journal of Forest Research, 31(11), 18551870. doi: $10.1139 / \mathrm{x} 01-120$

Safou-Matondo, R., Deleporte, P., Laclau, J. P., \& Bouillet, J. P. (2005). Hybrid and clonal variability of nutrient content and nutrient use efficiency in Eucalyptus stands in Congo. Forest Ecology and Management, 210(1), 193-204. doi: 10.1016/i.foreco.2005.02.049

Santa-Regina, I. (2000). Biomass estimation and nutrient pools in four Quercus pyrenaica in Sierra de Gata Mountains, Salamanca, Spain. Forest Ecology and Management, 132, 127-141. doi: 10.1016/S03781127(99)00219-4

Santa-Regina, I. \& Tarazona, T. (2001). Nutrient pools to the soil through organic matter and throughfall under a Scots pine plantation in the Sierra de la Demanda, Spain. European Journal of Soil Biology, 37(2), 125-133. doi: 10.1016/S1164-5563(01)01072-X 
Semwal, R. L., Maikhuri, R. K., Rao, K. S., Sen, K. K., \& Saxena, K. G. (2003). Leaf litter decomposition and nutrient release patterns of six multipurpose tree species of Central Himalaya, India. Biomass and Bioenergy, 24(1), 3-11. doi: 10.1016/S0961-9534(02)00087-9

Sileshi, G. \& Mafongoya, P. L. (2007). Quantity and quality of organic inputs from coppicing leguminous trees influence abundance of soil macrofauna in maize crops in eastern Zambia. Biology and Fertility of Soils, 43(3), 333-340. doi: 10.1007/s00374-006-0111-8

Silver, W. L., Hall, S. J., \& Gonzáles, G. (2014). Differential effects of canopy trimming and litter deposition on litterfall and nutrient dynamics in a wet subtropical forest. Forest Ecology and Management, 332, 47-55. doi: 10.1016/j.foreco.2014.05.018

Secretaría de Programación y Presupuesto-Instituto Nacional de Geografía e Informática (1986). Síntesis geográfica del estado de Nuevo León. México: SPP-Inegi.

Steel, R. G. D. \& Torrie, J. H. (1980). Principles and procedures of statistics: A biometrical approach (2nd ed.). New York, USA: McGraw-Hill Book Company.

Sundarapandian, S. M. \& Swamy, P. S. (1999). Litter production and leaflitter decomposition of selected tree species in tropical forests at Kodayar in the Western Ghats, India. Forest Ecology and Management, 123(2-3), 231-244. doi:10.1016/S0378$\underline{1127(99) 00062-6}$

Swamy, S. L., Kushwaha, S. K., \& Puri, S. (2004). Tree growth, biomass, allometry and nutrient distribution in Gmelina arborea stands grown in red lateritic soils of central India. Biomass and Bioenergy, 26(4), 305-317. doi: 10.1016/j.biombioe.2003.08.007

Vázquez, C. \& Orozco, A. (1996). La destrucción de la naturaleza. México, D.F: Fondo de Cultura Económica.

Vitousek, P. (1982). Nutrient cycling and nutrient use efficiency. American Naturalist, 119(4), 553-572.

Wackerly, D. D., Mendenhall, W., \& Scheaffer, R. L. (2002). Mathematical statistics with applications (6 $6^{\text {th }}$ ed.). Pacific Grove, California, USA: Duxbury.
Weltzin, J. F., Keller, J. K., Bridgham, S. D., Pastor, J., Allen, P. B., \& Chen, J. (2005). Litter controls plant community composition in a northern fen. Oikos, 110, 537-546. doi: 10.1111/i.00301299.2005.13718.x

Yang, W. Q., Wang, K.Y., Kellomäki, S., \& Zhang, J. (2006). Annual and monthly variations in litter macronutrients of three subalpine forests in Western China. Pedosphere, 16(6), 788-798. doi: $\underline{10.1016 / \text { S1002-0160(06)60115-X }}$

Zaldívar-Jiménez, A., Herrera-Silveira, J., Coronado-Molina, C., \& Alonzo-Parra, D. (2004) Estructura y productividad de los manglares en la reserva de la biosfera Ría Celestún, Yucatán, México. Madera y Bosques, 10(Núm. esp.), 25-35. doi: $\underline{10.21829 / \text { myb.2004.1031264 }}$

Zhang, H., Yuan, W., Dong, W., \& Liu, S. (2014). Seasonal patterns of litterfall in forest ecosystem worldwide. Ecological Complexity, 20, 240-247. doi: 10.1016/j. ecocom.2014.01.003

Received: 17 August 2017

Accepted: 3 March 2019

Published: 13 December 2019

This paper must be cited as:

González-Rodríguez, H., López-Hernández, J. M., RamírezLozano, R. G., Gómez-Meza, M., V., Cantú-Silva, I., SarquísRamírez, J. I., \& Mora-Olivo, A. (2019) Litterfall deposition and nutrient return in pine-oak forests and scrublands in northeastern Mexico. Madera y Bosques, 25(3), e2531514. doi: 10.21829/myb.2019.2531514

Madera y Bosques by Instituto de Ecología, A.C. is distributed under a Creative Commons Licence Attribution-NonCommercial-ShareAlike $\quad 4.0$ Internacional. 